\title{
Introduction: Commercialization of Academic Science and a New Agenda for Science Education
}

\author{
Gürol Irzik
}

Published online: 23 February 2013

(C) Springer Science+Business Media Dordrecht 2013

\begin{abstract}
Certain segments of science are becoming increasingly commercialized. This article discusses the commercialization of academic science and its impact on various aspects of science. It also aims to provide an introduction to the articles in this special issue. I briefly describe the major factors that led to this phenomenon, situate it in the context of the changing social regime of science and give a thumbnail sketch of its costs and benefits. I close with a general discussion of how the topic of commercialization of academic science is relevant to science education.
\end{abstract}

Keywords Commercialization - Scientific research · Nature of science ·

Science education

\section{The Meaning and Scope of Commercialization}

Science educators might wonder what the commercialization of academic science has to do with science education. The main aim of this special issue is to show that this is indeed a topic that deserves serious attention by the community of science educators for the purposes of science education. The commercialization of academic science is a multifaceted, complex process with economic, political, legal, cultural, ideological and educational dimensions, many of which are examined in the articles in this volume.

It may be useful at the outset to clarify the meaning and scope of commercialization in the context of this special issue and distinguish between "the commercialization of science", "the commercialization of academic science", and "the commercialization of higher education". By "the commercialization of higher education", I mean selling the non-scientific work of universities such as athletic and educational services for profit. Historical research reveals that the commercialization of higher education dates back to the nineteenth century in the US and until the mid-seventies "was largely confined to the

G. Irzik $(\bowtie)$

Faculty of Arts and Social Sciences, Sabanci University, Orta Mahalle,

Üniversite Caddesi No: 27, 34956 Tuzla, Istanbul, Turkey

e-mail: irzik@sabanciuniv.edu 
periphery of campus life: to athletic programs and, in a few institutions, to correspondence schools and extension programs" (Bok 2003, p. 3; see also ibid. pp. 35-56 and 81-92; Sperber 2004). The term "academic science" refers to science done in the universities as opposed to science done in research centers and laboratories of business firms. Hence, the commercialization of academic science is a subset of the commercialization of scientific activity and its results wherever it occurs, whether it is carried out in the universities or in for-profit research centers and laboratories. Again, in the US context, while both phenomena and the university-industry relations are at least a century old, the commercialization of academic science, which is the focus of this special issue, has reached unprecedented levels both in size and scope since the mid-seventies (Bok 2003, pp. 1-17; Good 2004; Washburn 2005, pp. 23-72).

The commercialization of academic science, though observed most widely and strikingly in the US, is also occurring in the European Union in varying degrees. Especially conspicuous in disciplines such as genetics and genetic engineering, biomedicine, pharmacology, computer science, communication and information sciences, it refers to the fact that academic scientific research is being done increasingly for profit and that its results are commodified through mechanisms of intellectual property, primarily patents, copyrights and licensing. Commercialization of academic science thus involves, but is not confined to, the commodification of academic research; it pervades the entire university culture. ${ }^{1}$ Hans Radder usefully distinguishes between a narrow and a broad sense of academic commodification: "In a narrow sense commodification is identified with commercialization, that is, the pursuit of profit by academic institutions through selling the expertise of their researchers and the results of their inquiries...[In a wider sense] academic commodification means that all kinds of scientific activities and their results are predominantly interpreted and assessed on the basis of economic criteria" (Radder 2010b, p. 4). In this special issue, I use the term "commercialization of academic science" to refer to both senses.

\section{The Commercialization of Academic Science and Science's Changing Social Regime}

The commercialization of academic science is closely tied to the changing social regime of science. The old regime, which owed much to the spectacular successes of science in military and medical fields especially during and after World War II, found its most succinct formulation in the 1945 report to the US President Franklin Roosevelt, Science-The Endless Frontier, written by Vannevar Bush. The report outlined a "social contract" between science and the state: while the state would set the research prerogatives and provide generous funds for their pursuit by the scientific community, scientists would educate future citizens, carry out "basic research" freely and produce discoveries which could hopefully then be developed into useful products by the industry for the benefit of the whole society. Accordingly, the report envisioned that universities would be the major actors in producing "basic" science and enjoy a high degree of internal autonomy and academic freedom.

\footnotetext{
1 Bok (2003), Greenberg (2001), Krimsky (2004), Mirowski and Sent (2008), Radder (2010a), Slaughter and Leslie (1997), Washburn (2005). See also Kleinman and others, this volume.
} 
Beginning in the mid-seventies, however, this regime started to break down under the pressure of forces that ultimately gave rise to the "entrepreneurial universities". These can be summarized as follows: ${ }^{2}$

\subsection{Economico-political}

Beginning in the 1970s the economies of the most developed countries entered a new phase and became "knowledge economies", where expert knowledge, which is above all scientific knowledge, became a factor of production more important than labor, land and money, and of primary importance in establishing and maintaining economic competitiveness. Knowledge economies gained impetus from new forms of cooperation between universities and industry, more specifically, a technology transfer from the former to the latter in order to capitalize scientific knowledge. For example, the Bayh-Dole Act of 1980 in the US gave universities and private companies the right to patent the results of publicly funded research. At the same time, globalization became a reality more than ever, and global economic competition between countries reached new heights. With Reaganism in the US and Thatcherism in UK, neoliberal economic policies swept the world. National barriers against the free mobility of capital were removed and privatization came to be seen as the magical panacea to all economic problems, from unemployment to public service inefficiency.

\subsection{Ideological}

An ideology of neoliberalism accompanied these and similar arrangements. It was argued that a free, unregulated market economy was the most efficient mechanism for the allocation of resources. Accordingly, universities began to be seen as firm-like entities that needed to be guided by economic values such as efficiency, productiveness and profit. Universities were pushed to become entrepreneurial, and when coupled with the fear that their budgets would be cut due to economic concerns, they received the ideology positively to a great extent (Kleinman and others, Oliveira, this volume).

\subsection{Legal}

Essentially, computer programs became copyrightable in the US in the mid-seventies, and a crucial US Supreme Court decision in 1980 opened the gate for patenting both genetically modified living creatures and the genetic material itself. In the famous Diamond v. Chakrabarty case, the Supreme Court ruled that artificially created organisms could be patented under the US Patent Act. Soon after the Supreme Court decision, patents for DNA, RNA, proteins, cell lines, genes, genetic tests, gene therapy techniques, recombinant RNA techniques, genetically modified plants and even whole living animals were allowed by the US Patent and Trademark Office.

\footnotetext{
${ }^{2}$ I have extracted this summary from a number of sources in addition to the articles in this volume, which I refer below wherever appropriate. See Bok (2003), Greenberg (2001), Irzik (2007), Kenny (1986), Krimsky (2004), Mirowski and Sent (2008), Radder (2010a), Slaughter and Leslie (1997), Stein (2004), and Washburn (2005).
} 


\subsection{Scientific}

In the last several decades, the world witnessed the revolutionary emergence of what has come to be called "technosciences" such as computer science and technology, communication and information technologies, biomedicine, genetics and genetic engineering. Two features of technosciences are immediately apparent: first, they are predominantly technology oriented (hence the name "technoscience"); second, they hold the potential to respond to the demands of a globalized market by producing potentially lucrative innovations.

The leading US universities responded positively to these developments. In exchange for substantial funds, they offered business firms not only expert labor power, labs and equipment, but also prior or privileged access to the results of scientific research and shared or sole ownership of patents. While still holding their university positions and often with the explicit encouragement of the university administration, many scientists became consultants, CEO's or partners in these firms, and others have started their own companies, making literally millions of dollars. In short, the US universities became entrepreneurial. This phenomenon quickly spread across many European countries, and by now it is difficult to find a university science program operating without any commercial aspiration (Kleinman and others, Knuuttila, Sjöström, Oliveira, this volume).

As a result of these economic, political, legal, ideological, and scientific developments, a new social regime of science has emerged, described variously in the relevant literature as "the new social contract" (Jasanoff 2005), "post-academic science" (Ziman 1996), "Mode 2 science" (Gibbons et al. 1994; Nowotny et al. 2001), "triple helix" of university-industry-state (Etzkowitz 2008) and "globalized privatization regime" (Mirowski and Sent 2008). While these labels express somewhat contrasting conceptualizations, there is substantial consensus that the new regime is based on capitalization of knowledge through an ever-expanding system of intellectual property rights, the increasing privatization of publicly funded research, and unprecedented collaboration between the university and industry, all of which contributed to the idea of an "entrepreneurial university" whose main task is to sell its intellectual work and expertise for profit. It is for this reason that a central aspect of the new social regime of science is nothing short of the commercialization of academic science.

\section{The Impact of Commercialization on Science}

The impact of the commercialization of academic science on science has been far ranging. Although some scholars have welcomed it, arguing that it is both inevitable and beneficial, many believe that it comes at too high a price.

Proponents point out that commercialization stimulates innovations in the universities, encourages deeper university-industry relations, capitalizes knowledge and thus contributes to the economic development. Indeed, US universities increased their patents tenfold by the year 2000 and earned 1.3 billion dollars in royalties and license fees in 2005; over five hundred spin-off companies were launched in 2006 alone, and the industry's share in academic research and development spending has risen from $2.3 \%$ in the 1970 s to almost $8 \%$ in 2000 and stabilized around that figure (Bok 2003, p. 12; Sterckx 2010, p. 45). A somewhat similar trend can be observed in Europe as well (Sterckx 2010, p. 45-46). Commercialization benefits not only universities of course, but also individual scientists to the extent that it provides them with new opportunities to fund and profit from their 
research. It also benefits private business firms because they can capitalize on the new inventions they have invested in and thereby increase their profits.

Critics of this trend, on the other hand, argue that commercialization comes at a very high price; they claim that it affects almost every aspect of science negatively, especially in disciplines such as biomedicine, genetics and pharmacology. Here is a schematic summary of those costs:

- Direction of research Commercialization skews the direction of scientific research toward what is patentable and profitable. Thus, research interests are increasingly shaped by commercial and corporate interests rather than by scientific value or social utility (Brown 2010; Irzik 2007; Resnik 2010).

- Methodology and research findings A number of studies indicate that private funding can bias the outcome of scientific research and is statistically associated with malpractice in random clinical trials, which form the golden methodological standard in testing the efficacy of drugs. ${ }^{3}$

- Intellectual commons With its ever-widening regime of intellectual property, commercialization has the effect of shrinking the space of intellectual commons. This may stifle scientific progress since new knowledge builds upon the old, and the legal difficulty of navigating patent law makes further innovation dispiriting and costly. ${ }^{4}$

- Conflicts of interest The increasing prevalence of corporate-sponsored university research is giving rise to unprecedented conflicts of interest with alarming consequences: biased research results, compromised objectivity in evaluating research proposals, and a threatened "ethos of science". 5

- The ethos of science Science has an ethos; that is, there are a number of attitudes, ethical norms and values which guide scientific activity. These include not only Mertonian norms like disinterestedness (more commonly known as objectivity) and common ownership of scientific knowledge and discoveries (i. e. communalism), but also honesty, openness, freedom, respect for subjects and the environment, and social responsibility. There is evidence that the commercialization of science is undermining various components of the ethos of science: ${ }^{6}$ it is damaging objectivity by biasing the evaluation of research proposals and research itself; financial interests constitute a serious risk factor for misconduct, which violates the norm of honesty; it fosters secrecy, undermining the spirit of openness and cooperation; shrinking the space of intellectual commons obviously conflicts with the common ownership of scientific knowledge and discoveries. Moreover, the non-disclosure clauses that are often included in the protocols between a university and the private company that sponsors its research sometimes results not only in secrecy, but also in the researcher's loss of control over her findings and the freedom to disseminate those findings through publication.

- The reward system in science With commercialization the reward shifts from recognition and esteem to monetary gain. Even though the commercial achievements of scientists are often excluded from tenure decisions, they are nevertheless valued very

\footnotetext{
3 Angell (2005), Brown (2010), Krimsky (2004, ch. 9), Musschenga et al. (2010), Washburn (2005, pp. 113-115).

4 Jasanoff (2005, ch. 8), Krimsky (2004, ch. 4), Vermeir, this volume.

5 Cauchon (2000), Krimsky (2004, ch. 8), Resnik (2007, pp. 23-28), Resnik (2010), Thompson et al. (2001).

${ }^{6}$ Bok (2003, pp. 66-71 and 144-151); Carrier this volume, Greenberg (2001, p. 357), Krimsky (2004); chs. 4, 5, 8 and 9; Oliveira, this volume; Radder (2010b), Resnik (2010); Vermeir, this volume.
} 
highly-especially by university administrators. Thus, scientists who achieve commercial success through their scientific research and expertise tend to receive higher salaries, enjoy more staff support and freedom from teaching responsibilities (Holbrook and Dahl 2004; Stein 2004).

- Social status of science The public holds science in high esteem. They generally have confidence in the findings of science; they trust scientists' judgments especially in matters of health and environment, and count on the independent critical voice of the scientific community to self-regulate and provide accurate information. The image of a scientist who is secretive, biased, and motivated more by money than by truth may erode public confidence in the results of science and undermine science's social legitimacy (Irzik 2007).

\section{The Articles in this Volume at a Glance}

The contributions to this volume examine the commercialization of academic science in relation to the changing social regime of science and its impact on various aspects of science. Drawing on both theoretical analysis and empirical case studies of actual scientific and institutional practices, they reflect the complexity of the phenomenon by critically scrutinizing it from different, but often intertwining perspectives: historical, sociological, cultural, communicational, economic, philosophical, and educational. Not content with criticism, a number of the articles also explore the possibility of models alternative to commercialized science.

Daniel Lee Kleinman, Noah Weeth Feinstein and Greg Downey in "Beyond Commercialization: Science, Higher Education and the Culture of Neoliberalism" argue that the intertwining of science and commerce should be discussed in the broader context of neoliberalism that has pervaded university culture. By presenting two cases of institutional change in a prestigious US university, the authors highlight the concrete strategic and rhetorical form neoliberalism takes in practice and how it affects the university culture, drawing attention to "the complicated, contradictory and hybrid character of neoliberalism".

Sibel Erduran and Ebru Mugaloglu in "Interactions of Economics of Science and Science Education: Investigating the Implications for Science Teaching and Learning", point out that the economics of science is a neglected a topic in science education and that it has a proper place in discussions on the nature of science, especially given the recent emphasis on understanding "science in context". First, they construct an example of a student activity to show how patenting affects the fact/artifact and discovery/invention distinction in the context of genes. They then apply "market economy" as a metaphor to models and modeling in science education in order to enrich understanding of the dynamics of model use for educational purposes.

Jesper Sjöström's "Eco-Driven Chemical Research in the Boundary between Academia and Industry-PhD Students' Views on Science and Society" examines, on the basis of indepth interviews, the views of science and society held by PhD students working in industrially- and environmentally-driven research in the field of "green chemistry" in Sweden. The article discusses students' views in relation to Mode 1, Mode 2, and Mode 3 science and concludes that few students have an idea of the larger social context of their work and few take a critical attitude toward their research.

Tarja Knuuttila in "Science in a New Mode: Good Old (Theoretical) Science versus Brave New (Commodified) Knowledge Production?", questions the tenability of a clear-cut 
distinction between Mode 1 and Mode 2 science, according to which whereas Mode 1 science is primarily basic, disciplinary and homogenous, disinterested and context-free, Mode 2 science is more application oriented, transdisciplinary, and heterogeneous to the extent that knowledge is produced by a multiplicity of actors and sites. On the basis of a case study of the commercialization of language technology in Finland and of a critical philosophical analysis, she shows that Mode 1 science shares many features of Mode 2 science and vice versa.

Marcos Barbosa de Oliveira, in his article "On the Commodification of Science: The Programmatic Dimension", provides a comparative historical overview of the changing social regime of science in the US and Brazil. After providing a summary of the Vannevar Bush report and the views of the economist Christopher Freeman, a pioneer of innovationism that became the core strategy behind the neo-liberal commodification of scientific research, Oliveira draws attention to some of the negative consequences of the new regime of commodified science and discusses "democratic science" as a viable alternative.

Koen Vermeir in "Scientific research: Commodities or Commons", discusses the positive and negative effects of what he calls "the free market economy of science" and examines two alternative models of science organization: scientific commons and the gift economy. He argues that a commons structured gift economy is more suited to the character of scientific knowledge and the norms that sustain it. The article ends by considering the possibility and the desirability of a hybrid model that takes the best of both the gift and the free market economies of science.

Loet Leydestorff's "Sociological and Communication-Theoretical Perspectives on the Commercialization of the Sciences", on the other hand, approaches the topic of commercialization of science via the "Triple Helix model" of university-industry-government relations by making use of essentially communication-theoretical perspectives. Leydestorff argues that this model provides a rich empirical framework since it allows for both institutional and evolutionary analysis of these relations in terms of novelty production, wealth generation, and political control. An attractive feature of this approach to science, he claims, is that it enables the researcher to empirically investigate how commercial and public interests may play out in different sciences in different countries.

Jordan Bartol in "Re-examining the Gene in Personalized Genomics", looks at the new commercial enterprise of "personalized genomics" (hereafter PG) which offers genetic testing to consumers, and analyzes the concept of gene presented. Bartol argues that PG companies employ two different concepts of gene in relation to genetic causation even though only one features in the underlying science. Genes are presented, on the one hand, as autonomous determiners of traits and, on the other hand, as to some extent constrained by environmental factors and thus as less autonomous. Bartol notes that PG involves the topics of communication and public understanding of genetics, both of which require empirical investigation.

Last, but not least, Martin Carrier's "Values and Objectivity in Science: Value-Ladenness, Pluralism and the Epistemic Attitude" develops a non-Baconian, social account of objectivity that preserves an analytical distinction between epistemic (or fundamental) and applicationoriented research. Carrier construes the objectivity of epistemic research in terms of a pluralism of epistemic and non-epistemic values and norms at the level of scientific reasoning on the one hand, and in terms of what he calls "the epistemic attitude", that is, "the willingness of scientists to subject their claims to empirical scrutiny and to respect rational argument" at the level of social conventions that enable scientists to handle their competing claims on the other. Carrier points out how, according to his account, commercialized science can fail to be objective by violating the (Mertonian) norms of disinterestedness and common ownership of scientific knowledge. 


\section{Concluding Reflections on the Relevance of the Commercialization Science to Science Education}

As Erduran and Mugaloglu's article emphasizes, the topic of the commercialization of science opens up a new area of research in science education: namely, the economics of science, which is virtually unexplored. Given the wide consensus within the NOS research that science is a socially embedded enterprise influenced by all sorts of social factors, the economics of science appears to be a perfectly legitimate and even necessary domain of research since economic factors are clearly part of the generic notion of social factors. In this special issue we have compiled many examples of these factors at work in science. Science has a huge economic dimension, the examination of which can contribute significantly to a deeper understanding of NOS, in line with the recent emphasis on learning and teaching "science in context" or "authentic science". The defenders of this approach to science argue that issues arising from science-technology-society interactions, social norms of science, and funding and fraud all should receive more attention in discussions of NOS (see, for example, Sadler 2011; Weinstein 2008; Wong and Hodson 2010; Zemplen 2009; see also the special issue of the journal Science \& Education vol. 17, nos. 8-9, 2008).

The trend towards the commercialization of science shows the need to understand NOS systematically and in a much broader context than is usually provided in the science education literature. As the articles in this volume amply demonstrate, the commercialization of science affects not just scientific knowledge production, but also science's culture and ethos, its reward system, its status and social functions. Hence, commercialization forces us to think of science from an institutional perspective as well, calling us to realize that science is not just an epistemic system of thought and activity of knowledge production, but is also a social institution embedded in the larger society. While unpacking this requires a separate study of its own, some general remarks might suffice here.

To approach science as a social institution is to view it as having a structural organization embodying a community of specialists (think of scientists in a university setting) carrying out certain tasks in accordance with specific methodological and ethical rules regulating the performance of those tasks (think of testing of theories subject to ethical constraints like avoiding harm to people and the environment). It also involves the recognition that science has an institutional culture, an ethos, comprised of often implicit norms, values, and attitudes such as intellectual honesty, openness, freedom of research, free and critical exchange of ideas, and common ownership of scientific knowledge. It requires the acknowledgment that science has a system of certification (e.g. peer review) and dissemination of knowledge (through, for example, publications and conferences) and that science has certain institutional functions that give it legitimacy in the eyes of the public, such as improving their health and living conditions, informing them about matters of general concern, and contributing to economic development (Kitcher 2001; Miller 2011; Irzik and Nola forthcoming).

There is, I believe, a need to study NOS from this broad perspective if we want our students, some of whom are no doubt our future scientists, to have a full understanding of science in today's world. What is needed is to bring all aspects of science, epistemic and institutional, under a systematic and comprehensive framework that shows how they relate to one another and indeed cooperate to achieve science's various goals and functions. ${ }^{7}$ In particular, science education may benefit greatly from an in-depth discussion of how science's social conventions, its ethical norms and values, and its social system of certification help produce reliable and objective knowledge.

\footnotetext{
${ }^{7}$ For an effort in this direction see Irzik and Nola (forthcoming).
} 
Finally, the commercialization of academic science forces us to think hard about the role of science in today's world. What is the proper balance between the epistemic and social functions of science? In other words, how much research should be done just for the sake of knowing and how much research should be done for social utility? If science is to contribute to the economy, is commercializing it the right way to achieve this? Should the commercialization of academic science be resisted, given its costs? What are the social responsibilities of scientists and science educators as the social regime of science is going through this massive transformation? These are some of the pressing questions the theme of this special issue leaves us with.

Acknowledgments I am grateful to Emily Coolidge Toker for her comments which considerably improved this article and also for her generous help with the entire process of preparing this volume. I could not have done it without her. I thank the authors for their contributions, cooperation and patience. Thanks also go to all the scholars, too numerous to cite here, for their meticulous reviews of the submitted manuscripts. Last but not least, I am indebted to Michael Matthews for his invaluable advice and assistance and above all for making this special issue possible.

\section{References}

Angell, M. (2005). The truth about the drug companies. New York: Random House.

Bok, D. (2003). Universities in the market place. Princeton: Princeton University Press.

Brown, J. R. (2010). One-shot science. In H. Radder (Ed.), The commodification of academic research (pp. 90-109). Pittsburgh: University of Pittsburgh Press.

Cauchon, D. (2000). FDA advisers tied to industry. USA Today, September 25.

Etzkowitz, H. (2008). The triple helix. New York: Routledge.

Gibbons, M., Limoges, C., Nowotny, H., Schwartzman, S., Scott, P., \& Trow, M. (1994). The new production of knowledge. London: Sage.

Good, M. L. (2004). Increased commercialization of the academy following the Bayh-Dole act of 1980. In D. G. Stein (Ed.), Buying in or selling out? (pp. 48-55). New Brunswick: Rutgers University Press.

Greenberg, D. S. (2001). Science, money, and politics. Chicago: The University of Chicago Press.

Holbrook, K. A., \& Dahl, E. C. (2004). Conflicting goals and values: When commercialization enters into tenure and promotion decisions. In D. G. Stein (Ed.), Buying in or selling out? (pp. 88-102). New Brunswick: Rutgers University Press.

Irzik, G. (2007). Commercialization of science in a neoliberal world. In A. Bugra \& K. Agartan (Eds.), Reading Polanyi for the twenty-first century (pp. 135-154). New York: Palgrave MacMillan.

Irzik, G., \& Nola, R. (forthcoming). New directions for nature of science research. In M. Matthews (Ed.), Springer handbook of historical and philosophical studies in science education. Dordrecht: Springer.

Jasanoff, S. (2005). Designs on nature. Princeton: Princeton University Press.

Kenny, M. (1986). Biotechnology: The university-industrial complex. New Haven: Yale University Press.

Kitcher, P. (2001). Science, truth, and democracy. Oxford: Oxford University Press.

Krimsky, S. (2004). Science in the private interest. Lanham: Rowman and Littlefield.

Miller, S. (2011). Social institutions. http://plato.stanford.edu/entries/social-instutions/.

Mirowski, P., \& Sent, E.-M. (2008). The commercialization of science and the response of STS. In E. J. Hackett, O. Amsterdamska, M. Lynch, \& J. Wajcman (Eds.), The handbook of science and technology studies (3rd ed., pp. 635-689). Cambridge: The MIT Press.

Musschenga, A. W., Steen, W. J., \& Ho, V. K. Y. (2010). The business of drug research: A mixed blessing. In H. Radder (Ed.), The commodification of academic research (pp. 110-131). Pittsburgh: University of Pittsburgh Press.

Nowotny, H., Scott, P., \& Gibbons, M. (2001). Rethinking science. Cambridge: Polity.

Radder, H. (Ed.). (2010a). The commodification of academic research. Pittsburgh: University of Pittsburgh Press.

Radder, H. (2010b). The commodification of academic research. In H. Radder (Ed.), The commodification of academic research (pp. 1-21). Pittsburgh: University of Pittsburgh Press.

Resnik, D. (2007). The price of truth. Oxford: Oxford University Press.

Resnik, D. (2010). Financial interests and the norms of academic science. In H. Radder (Ed.), The commodification of academic research (pp. 65-89). Pittsburgh: University of Pittsburgh Press. 
Sadler, T. D. (2011). Socio-scientific issues in the classroom. Dordrecht: Springer.

Slaughter, S., \& Leslie, L. L. (1997). Academic capitalism. Baltimore: The John Hopkins University Press. Sperber, M. (2004). College sports inc.: How big-time athletic departments run interference for college, inc. In D. G. Stein (Ed.), Buying in or selling out? (pp. 17-31). New Brunswick: Rutgers University Press. Stein, D. S. (2004). Buying in or selling out?. New Brunswick: Rutgers University Press.

Sterckx, S. (2010). Knowledge transfer from academia to industry through patenting and licensing: Rhetoric and reality. In H. Radder (Ed.), The commodification of academic research (pp. 44-64). Pittsburgh: University of Pittsburgh Press.

Thompson, J., Baird, P., \& Downie, J. (2001). The Olivieri report. Toronto: James Lorimer and Co.

Washburn, J. (2005). University Inc. New York: Basic Books.

Weinstein, M. (2008). Finding science in the school body: Reflections on transgressing the boundaries of science education and the social studies of science. Science Education, 92, 389-403.

Wong, S. L., \& Hodson, D. (2010). More from horse's mouth: What scientists about science as a social practice. International Journal of Science Education, 32, 1432-1463.

Zemplen, G. A. (2009). Putting sociology first-reconsidering the role of the social in nature of science. Science \& Education, 18, 525-560.

Ziman, J. (1996). Postacademic science: Constructing knowledge with networks and norms'. Science Studies, 9, 67-80. 